\title{
Theorising Digital Self-Mediation and the Smartphone as Filmic Apparatus after 6 January, 2021
}

Jenny Gunn

DOI: 10.15664/fcj.v18i1.2255

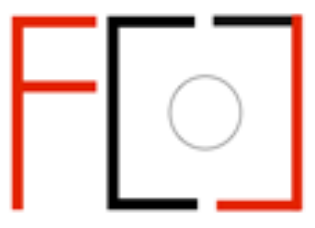

Frames Cinema Journal ISSN 2053-8812

Issue 18 (Jun 2021)

http://www.framescinemajournal.com

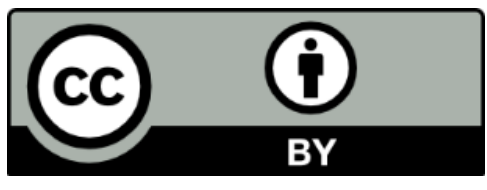




\section{Theorising Digital Self-Mediation and the Smartphone as Filmic Apparatus after 6 January, 2021}

Jenny Gunn

Undoubtedly, these are still early days in what is bound to be a robust response in the academic scholarship to the event of the United States Capitol insurrection on 6 January 2021. On this day, which was to mark the ceremonial counting of the Electoral college votes and thereby confirm Joe Biden as the $46^{\text {th }}$ president of the United States, a mob of Trump supporters instead proceeded from Trump's speech at the "Stop the Steal" rally held nearby on the Ellipse, marched to and ultimately stormed the U.S. Capitol in a violent attempt for the political benefit of President Donald Trump to halt the counting of the votes. ${ }^{1}$ As this essay argues, the Insurrection of 6 January is not only politically and historically significant but equally important to both media history and visual culture studies given its highly mediated nature. My comments here are thus inherently provisional; this piece does not intend to be the authority on the significance of 6 January but rather to present some observations, particularly concerning the pervasive usage of the smartphone camera to document the storming of the U.S. Capitol (Fig. 1). As mainstream media footage of the event clearly shows, many participants in the storming of the Capitol on 6 January willingly documented the event and their participation in it using their smartphone cameras (Fig. 2). Whether streamed live or later uploaded to social media sites from Facebook to Parler, the FBI would later utilise portions of this footage in the identification and arrest of suspects, a process that is ongoing. ${ }^{2}$ For digital media studies, however, the event of 6 January provides one of the most thorough documents of the usage of the smartphone as a filmic apparatus. Significantly, the event of 6 January as reconstructed belatedly - as for example in the Impeachment trial house managers' "supercut" or as captured live during the event by the mainstream news networks - provide an 
unusual record of the practice of smartphone mediation in media res. For scholars interested in the significance of the forward-facing camera as an ontological new media form, the event of 6 January would seem to mark a necessary turning point - perhaps one could argue a crisis point - that demands a thorough re-examination of this burgeoning research area.

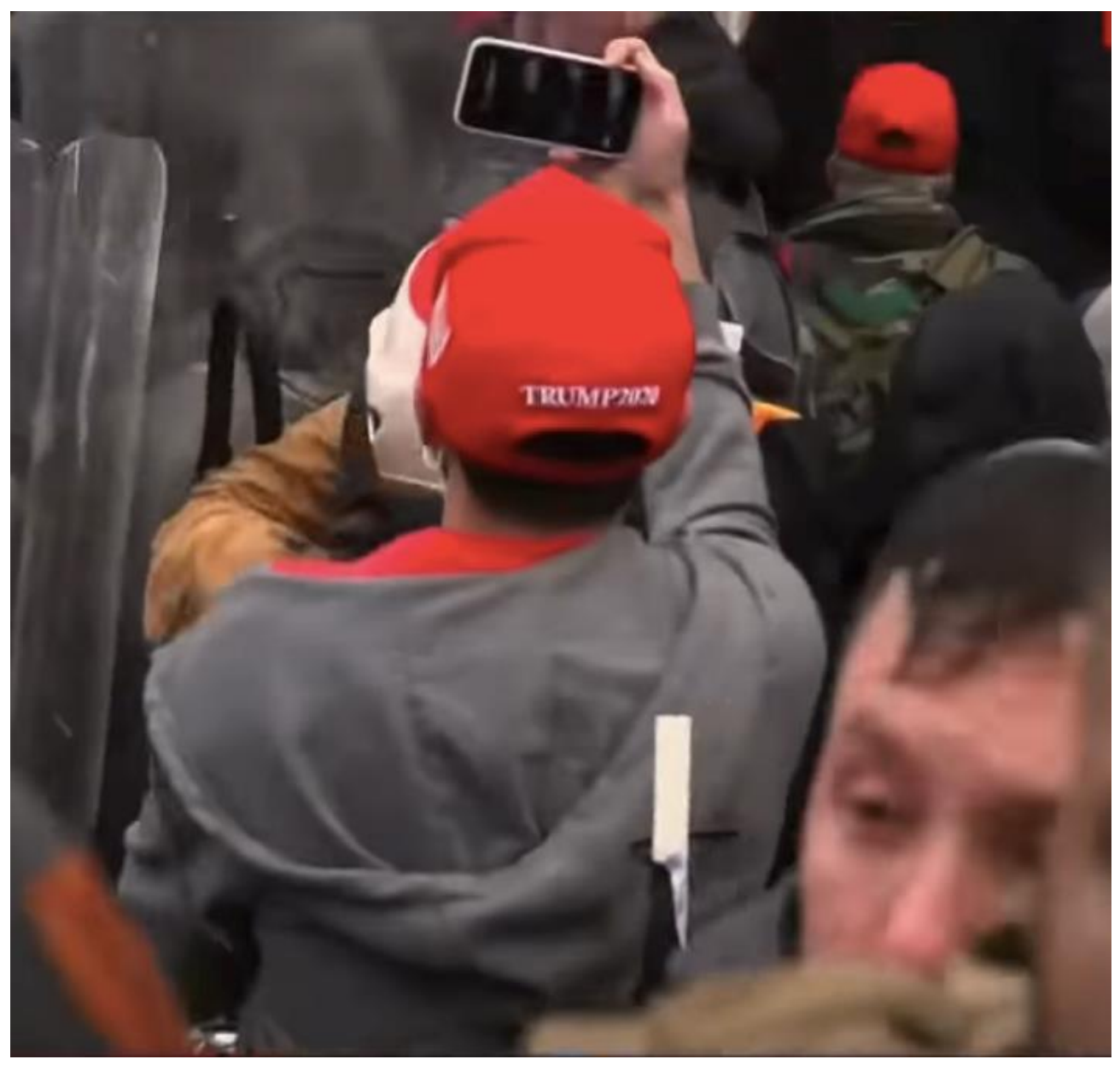

Figure 1: A Trump supporter films the Storming of the Capitol, screenshot, House Impeachment Managers' video of the Capitol Riot as presented at the Impeachment trial. 


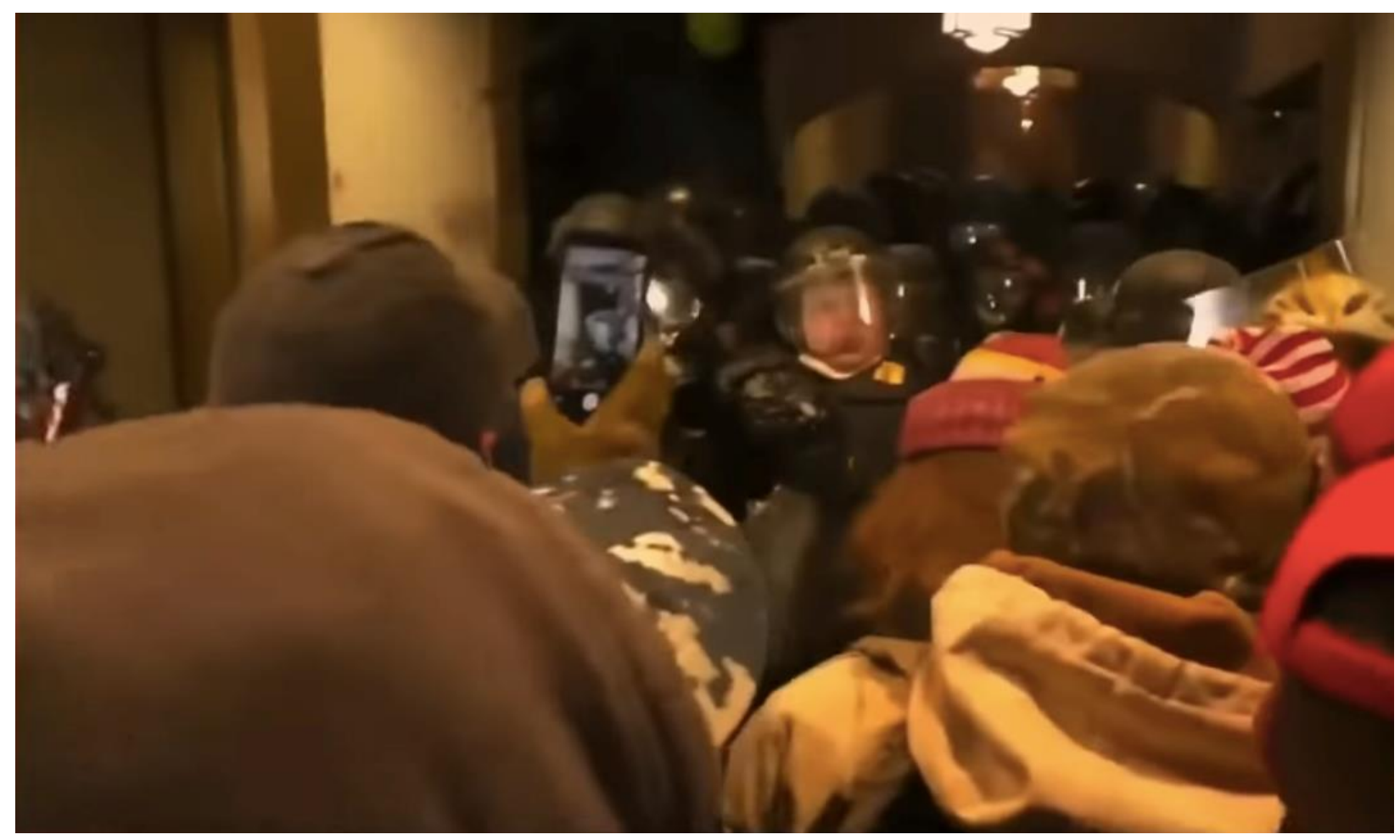

Figure 2: A rioter films as a crowd approaches the Capitol Police, Screenshot from the House Impeachment Managers' video of the Capitol Riot as presented at the Impeachment trial.

In his otherwise thorough response to 6 January as an event in the history of visual culture, W.J.T. Mitchell's blog entry for Critical Inquiry passes over the question of self-mediation as a major mode of engagement during the insurrection. ${ }^{3}$ Mitchell does address the riot as an "unrivalled spectacle", given the co-presence of both the mainstream news media and the cell phone cameras of the rioters themselves, but as to the question of self-mediation more specifically, Mitchell merely mentions twice in passing that rioters were taking and posing for "selfies". ${ }^{4}$ After the forward-facing camera became a standard smartphone feature in the early 2010s, theories of digital self-mediation primarily focused on the photographic format of the selfie. Although scholars such as Hannah Westley were right to insist that selfies are merely by-products of much more complex processes of automediality, nevertheless the selfie predominated both scholarly and popular media interest in the question of digital self-representation. ${ }^{5}$ While self-mediation as a 
moving image form has been addressed in digital media scholarship on vlogging and broadcasting, such studies are often practice- or platform-specific. What has been overlooked but is increasing visible across digital media applications, is the function of the smartphone camera as a filmic apparatus in which the mode of mediation crosses fluidly between objective and subjective modes, where the capture of reality in front of the lens is subject to interruption and put into a near constant dialectical relationship with the self. And yet, neither film nor digital media studies has contextualised this quality of the smartphone and its significance in the context of the theoretical history of the cinema.

This elaboration is necessary to understand participation in the storming of the Capitol as a simultaneously lived and mediated experience. Before provisionally examining the smartphone's social and subjective effects further, I would like to address something made more blatantly visible by the mediated event of the insurrection related to the demographics of the rioters as predominately white adult males. Initial scholarly and popular conversations surrounding the emergence of the selfie format were preoccupied with questions of the male gaze - whether women taking and sharing their own photographs were finally achieving feminist autonomy or, alternatively, internalising and finally succumbing to a full and now self-legislated objectification. ${ }^{6}$ Scholars such as Aria Dean have been right to point out how these conversations of the gaze reenact the gender essentialism of feminism's second wave, overlooking important questions of intersectional privilege. ${ }^{7}$ But the immediate assignation of digital self-mediation as a "women's issue" and an issue of representational politics alone also obscured the larger implications of the forward-facing camera as a new media form. This diminution of the impact of self-mediation to digital media culture is indeed foreshadowed - or perhaps overdetermined - in the likewise diminutive moniker attached to such practice of self-mediation in the early 2010s: selfie. 
The 2013 Oxford English Dictionary word of the year, the term selfie not only registers as a gendered assignation but is also associated dismissively with Millennial youth culture and an anxiety that the popularity of a narcissistic new media form foretold the destiny of a solipsistic new generation. (These concerns of course go doubly for young women, who are already interpellated through questions of female narcissism and the gaze). ${ }^{8}$ Admirably, then, pushing back against the association of the selfie with an epidemic of narcissism, much scholarship in digital media studies reclaims the progressive practices of self-mediation for democratic participation and minority community building. ${ }^{9}$ But in response to the insurrection of 6 January, it has become clear: even if you don't take selfies, that doesn't mean you don't self-mediate. As the demographic of the rioters would suggest, participation in self-mediation is a widespread form of digital media engagement that goes well beyond the users identified in the early scholarship just discussed (Fig. 3). As a result, the question of the social and subjective effects of self-mediation is much more global in nature than has been previously considered. But while I reject the limited scope of the conversations surrounding the advent of the forward-facing camera and practices of self-mediation in one sense, on the other hand, the event of 6 January suggests that we have perhaps not considered enough the question of the forward-facing camera as a narcissistic new media form nor the extent of its psycho-social and thus political impact. 


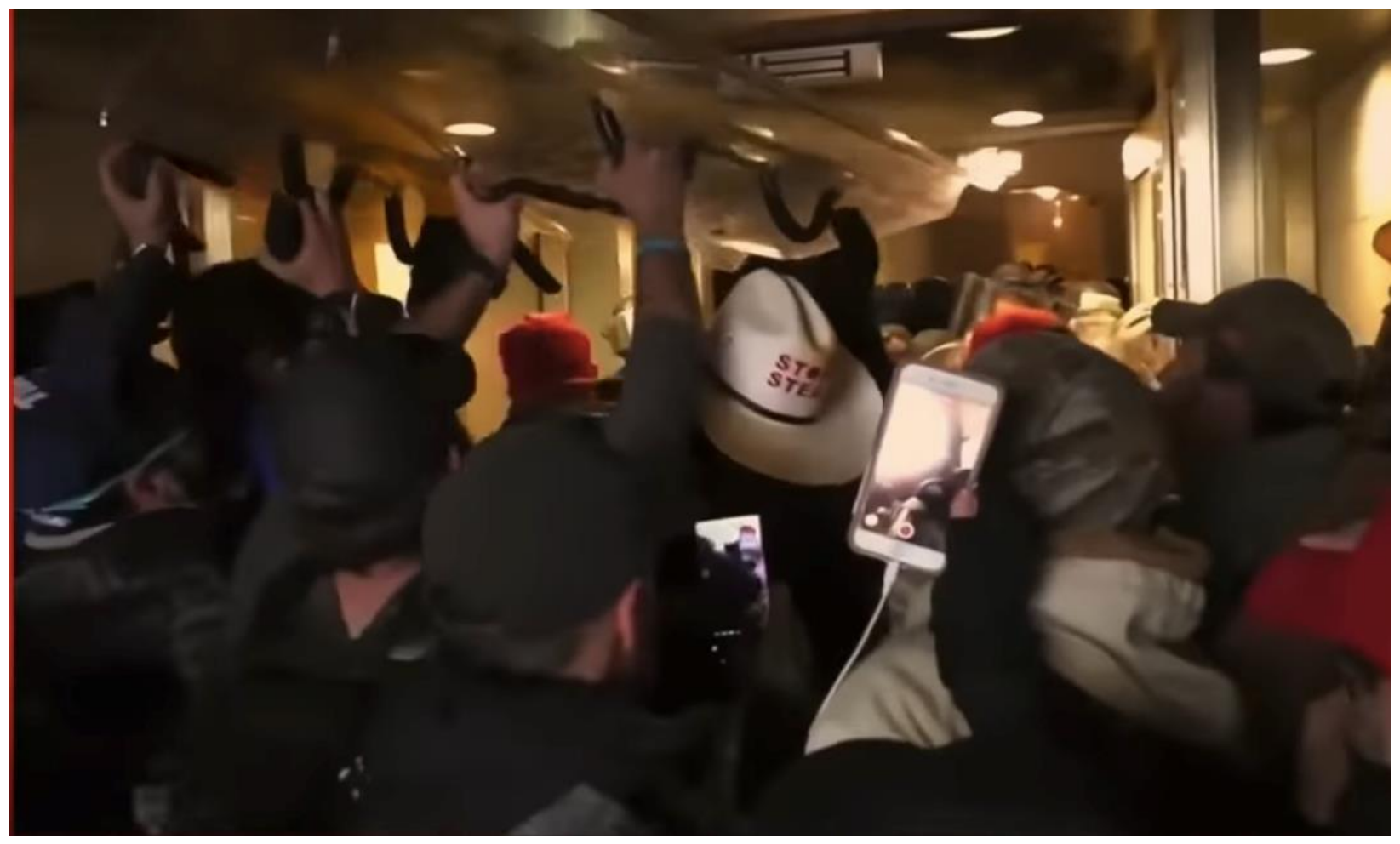

Figure 3: Two rioters film as they storm the Capitol using a Police Riot Guard, Screenshot from the House Impeachment Managers' video of the Capitol Riot as presented at the Impeachment trial.

The public appraisal of President Donald Trump as a narcissist in the U.S. news media is by now well-documented. ${ }^{10}$ Indeed, in his own account of the insurrection, Mitchell references political personality profiler Jerrold Post's book Dangerous Charisma, which advances a theory of a "mirror psychosis" occurring between the narcissist, Trump, and the wounded narcissism of his followers. ${ }^{11}$ While the development of the Trumpian base and the ultimate disinformation ecosystem that composes their worldview has been largely considered a consequence of the fragmented and partisan nature of social media sites and their proprietary algorithms that attract like to like and reward attention rather than accuracy, what has been less considered is the intersection of these realities with the emergence of self-mediation in this context as a major modality of digital media engagement. Put otherwise, on the one hand, we have the emergence of a narcissistic new media form, the forward-facing camera, and on the other, the election of Trump, 
someone widely viewed to be a malignant narcissist as president of the United States. ${ }^{12}$ Perhaps, one could argue, there is a connection here that is cause for further exploration, a political technogenesis of sorts.

If, as Freud tells us, a pathological narcissism interferes with the capabilities of external object relations, then would the development of a new avowedly narcissistic new media form, the forward-facing camera, and the intensified capacity to mediate the self that it offers, exacerbate the psychological condition of narcissism? ${ }^{13}$ Posing the same question in somewhat inverted form, Yasmin Ibrahim asks us to consider how, in tandem with the rise of social media networks, new media technologies and their further entrenchment around the subject through wearables and handheld devices such as the smartphone exploit the psychological condition of narcissism to increase our usage. ${ }^{14}$ Similarly, Jodi Dean has argued that the reflexivity characteristic of social media participation has caused what Slavoj Žižek describes as the decline of symbolic efficiency, leading to an endless and inconclusive proliferation of meanings radiating from the $\mathrm{I}^{15}$ Dean's earlier application of this concept to an analysis of blogging reads even more prophetically of today's fractured, partisan media landscape, which is widely understood to have led to the Trumpian worldview and more specifically his base's resulting faith in the "Big Lie" that the 2020 U.S. election was stolen in blatant disregard of all evidence to the contrary.

Recalling Dean's observation that with the decline of symbolic efficiency, "images and affective intensities may appear as all the more powerful, relevant, and effective," conservative columnist Peggy Noonan notes both a seeming detachment of rioters from the event of the insurrection in which they were participating, as if spectators at a remove, and a seemingly contradictory abundance of personal feeling circulating in place of political consensus or analysis based in rational basis after the fact. ${ }^{16}$ Noonan and Dean's shared alarm recalls digital media 
scholars Guinness and Bollmer's claim for the necessity of an ethics of self-mediation practices as a relational politics. They proscribe a so-called "phenomenology for the selfie" that evaluates the ethics of the relation established in any given selfie practice between the figure and its surrounding ground. ${ }^{17}$ Acknowledging a spectrum of narcissism, Bollmer and Guinness suggest that practices of self-mediation can be redeemed through the relational intentionality of a phenomenological subject. But digging deeper into theories of phenomenological intentionality would seem to suggest the need for a more nuanced account of the interplay between the technology of the smartphone and the self in its relation to the world.

Peter-Paul Verbeek's updated approach to Don Ihde's work on technologically mediated intentionality as "cyborg intentionality" is a useful place to begin to consider the phenomenological ramifications of the smartphone as a mediating apparatus, particularly Verbeek's concept of the cyborg's "hybrid intentionality" that merges human and technology into a new experiencing entity. ${ }^{18}$ To the question of self-mediation more specifically, Maren Wehrle's work on the double aspect of human embodiment is clarifying. ${ }^{19}$ While the experiential flow of having a body is the larger focus of phenomenology, as Wehrle argues via citation of the work of Thomas Fuchs, overt and sustained focus on the object of one's body can disrupt one's explicit sense of time, leading to a disorienting experience of discontinuity that Fuchs argues can cause, "a break in the affective attunement to the world." ${ }^{20}$ In addition to psychiatric pathologies such as depression and schizophrenia, Werhle cites the presence of mirrors and external gazes as more common causes for a momentary suspension of the continuity of the twofold. ${ }^{21}$ It seems here worth remarking that the schizophrenia Fuchs associates with an extreme version of such a state is for Freud synonymous with the diagnosis of pathological narcissism. ${ }^{22}$ Noting this conjunction, I do not intend a blanket diagnosis of contemporary culture but rather to encourage those of us in digital 
media studies to take up our methodological tools in order to take seriously the relationship between art and politics: to consider that, if narcissism is the basis for psycho-social identification, then there might be a through-line between the increasing engagement in practices of digital selfmediation and the exacerbation of not only the political polarisation but also the violence and white supremacy that undergird the 6 January insurrection. As Sara Ahmed describes of whiteness as a phenomenology, citing Fanon, the corporeal schema develops based on the historical racial schema that precedes and supports it. ${ }^{23}$ For every intentional object to which we do attend, Ahmed reminds us there are those that we overlook. ${ }^{24}$ Put otherwise, we might suggest that for whiteness, there is an interplay of narcissism (the development of a sense of self followed by identification with others in likeness as ego ideals) and phenomenology that may restrict its objects of intentionality. Selfmediation of our phenomenological experience might thus have the effect of further delimiting an already limited field and with worrisome ramifications.

In order to address the impact of the smartphone apparatus' unique admixture of subjective and objective modes, we might consider Pier Paolo Pasolini's analysis of the Zapruder film of the Kennedy assassination. In "Observations on the Long Take”, Pasolini discusses Zapruder's amateur recording of the Kennedy assassination to advance his theory of the nature of film. ${ }^{25}$ For him, the Zapruder film is the quintessential long take, synonymous with a first-person perspective, a single point of view. Like subjectivity itself, he argues, the long take is the "maximum conceivable limit of any audio-visual technique." ${ }^{26}$ To Pasolini, the inconclusive nature of the Zapruder film as objective evidence is located in its subjective nature. Providing the hypothetical scenario of a recording from the point of view of every witness in Dallas that day, Pasolini argues that this merely additive scenario would prove only more inconclusive: "This multiplication of 'presents,' abolishes the present, empties it, each present postulating the relativity of all others, 
their unreliability, imprecision, and ambiguity. ${ }^{, 27} \mathrm{He}$ continues, arguing that as the true intellectual art of film, only montage can cease this instability of meaning, "render the present past" and remake these merely subjective fragments into a legible and historically significant past-present. ${ }^{28}$ The theoretically limitless expansion of viewpoints Pasolini postulates through the example of Zapruder's film has now become reality via smartphone mediation and proves even less evidentiary. Mitchell observes with some perplexity the irony of some rioters' smashing of the equipment of the mainstream news media crews while simultaneously overlooking their own widespread filming of the event with their smartphones. ${ }^{29}$ On a related note, Peggy Noonan admonishes the right-wing media's defence of the legality of the events of 6 January on the basis that they were openly planned on social media. ${ }^{30}$ While the violence towards the mainstream news media among a crowd of Trump supporters might need little explanation, there seems amongst them a nevertheless unconscious understanding of the smartphone apparatus as a partial, merely subjective view of the event that lacks the objective conclusiveness of the television network cameras. Yes: as Mitchell and Noonan both insist, the storming of the capitol was a hyper-mediated event, but despite all the videographic evidence, Trump was not convicted during his second impeachment trial; the evidence itself was not conclusionary.

Writing in 1967, Pasolini could not appreciate the prescience of his conclusions - not the vast conspiracy theories the Kennedy assassination would go on to produce, much less those that fuel "The Big Lie" and the hyper-mediated event of 6 January, 2021, which, via the smartphone, fulfils and even exceeds the conditions of the then still hypothetical scenario Pasolini envisions would define cinema in its most subjective mode. For what Pasolini could not then imagine, is that for every living witness, there are now extensive and fragmented virtual audiences that redouble them on livestreams and social media networks. As this witness list expands, consensus weakens, 
and conspiratorial thinking exacerbates. Smartphone mediation and its tendency towards forwardfacing self-mediation and thus, the subjective mode are not incidental but critical components of the media and political history of the events of 6 January, the facts of which perhaps not coincidentally the U.S. polis still cannot and may not ever agree upon.

\section{Notes}

${ }^{1}$ For a thorough first-hand account of the events of 6 January 2021, see Luke Mogelson, "Among the Insurrectionists," The New Yorker, accessed May 28, 2021, https://www.newyorker.com/magazine/2021/01/25/among-the-insurrectionists.

${ }^{2}$ Ryan Lucas, "FBI Asks Public For Help Identifying Capitol Riot Suspects Seen Attacking Police," NPR.org, accessed April 23, 2021, https://www.npr.org/2021/03/18/978644288/fbiasks-public-for-help-identifying-capitol-riot-suspects-seen-attacking-police.

${ }^{3}$ W.J.T. Mitchell, "The Revolution Was Televised," In the Moment (blog), February 23, 2021, https://critinq.wordpress.com/2021/02/23/the-revolution-was-televised/.

${ }^{4}$ Ibid.

${ }^{5}$ Hannah Westley, "Reading the Self in Selfies," Comparative Critical Studies 13, no. 3 (2016): 371-90; for more on the history of the selfie see, Jenny Gunn, "Narcisscinema: Selfie Culture and the Moving Image" (PhD Dissertation, Atlanta, Georgia, Georgia State University, 2019). ${ }^{6}$ See for example, "Women, Selfies, and The Male Gaze - What Really Happens When Girls Take A Selfie," AMBmagazine.Com (blog), May 4, 2017, http://ambmagazine.com/womenselfies-male-gaze-really-happens-girls-take-selfie/; Gunn, "Narcisscinema: Selfie Culture and the Moving Image;" Jenny Gunn, "The Gaze in Millennial Culture: Selfies, Instagram and Richard Prince's "New Portraits"," in Material Culture and Third Wave Feminism, 2016, https://www.academia.edu/14738661/The_Gaze_in_Millennial_Culture_Selfies_Instagram_and Richard_Prince_s_New_Portraits_?source=swp_share.

${ }^{7}$ Aria Dean, "Closing the Loop," The New Inquiry 50 (March 1, 2016).

${ }^{8}$ Brooke Lea Foster, "The Persistent Myth of the Narcissistic Millennial," The Atlantic, November 19, 2014, https://www.theatlantic.com/health/archive/2014/11/the-persistent-myth-ofthe-narcissistic-millennial/382565/; Zoe Williams, "Me! Me! Me! Are We Living through a Narcissism Epidemic?," The Guardian, March 2, 2016, sec. Life and style, http://www.theguardian.com/lifeandstyle/2016/mar/02/narcissism-epidemic-self-obsessionattention-seeking-oversharing.

${ }^{9}$ See for example, Nicole Morse, "Selfie Aesthetics: Form, Performance, and Transfeminist Politics in Self-Representational Art" (PhD Dissertation, Chicago, IL, University of Chicago, 2018); Derek Conrad Murray, "Notes to Self: The Visual Culture of Selfies in the Age of Social Media - 10253866.2015.1052967," Consumption Markets \& Culture 18, no. 6 (July 7, 2015): 490-516.

${ }^{10}$ George T. Conway III, "Unfit for Office," The Atlantic, accessed April 23, 2021, https://www.theatlantic.com/ideas/archive/2019/10/george-conway-trump-unfit-office/599128/. 
11 Jerrold M. Post and Stephanie R. Doucette, Dangerous Charisma (Pegasus Books, 2020).

${ }^{12}$ In an earlier article, I have also linked the emergence of object-oriented philosophy in the 2010s to practices of self-objectification made possible by the forward-facing camera, see Jenny Gunn, "The I in Object: Selfie Culture and Object-Oriented Philosophy," Cinephile 12, no. 1 (Spring 2018): 48-53.

${ }^{13}$ Sigmund Freud, "On Narcissism," in The Standard Edition of the Complete Psychological Works of Sigmund Freud, trans. James Strachey, vol. XIV (Hogarth, 1957): 67-102.

${ }^{14}$ Yasmin Ibrahim, "Coalescing the Mirror and the Screen: Consuming the 'self' Online," Continuum 31, no. 1 (2017): 104-13.

15 Jodi Dean, Blog Theory: Feedback and Capture in the Circuits of Drive (Cambridge: Polity, 2010).

${ }^{16}$ Dean, 6; Peggy Noonan, "Opinion | A Vote to Acquit Trump Is a Vote for a Lie," Wall Street Journal, February 11, 2021, sec. Opinion, https://www.wsj.com/articles/a-vote-to-acquit-is-avote-for-a-lie-11613084456.

${ }^{17}$ Grant Bollmer and Katherine Guinness, "Phenomenology for the Selfie," Cultural Politics 13, no. 2 (July 2017): 156-76.

${ }^{18}$ Peter-Paul Verbeek, "Cyborg Intentionality: Rethinking the Phenomenology of HumanTechnology Relations," Phenomenology and the Cognitive Sciences 7, no. 3 (September 1, 2008): 387-95; Don Ihde, Technology and the Lifeworld: From Garden to Earth (Bloomington: Indiana University Press, 1990).

${ }^{19}$ Maren Wehrle, "Being a Body and Having a Body. The Twofold Temporality of Embodied Intentionality," Phenomenology and the Cognitive Sciences 19, no. 3 (July 1, 2020): 499-521.

20 Thomas Fuchs, "The Phenomenology of Body Memory" in S. C. Koch, T. Fuchs, \& M. Summa (Eds.), Body Memory, Metaphor and Movement (Amsterdam: John Benjamins Publishing, 2012): 9-23; Thomas Fuchs, "Temporality and Psychopathology" in Phenomenology and the Cognitive Sciences, 12, 2013: 75-104.

${ }^{21}$ Wehrle.

${ }^{22}$ Fuchs, "Temporality and Psychopathology;" Freud, "On Narcissism: An Introduction."

${ }^{23}$ Sara Ahmed, "A Phenomenology of Whiteness," Feminist Theory 8, no. 2 (2007): 153; Frantz Fanon, Black Skin, White Masks (London: Pluto Press 1986).

${ }^{24}$ Ahmed, 154.

${ }^{25}$ Pier Paolo Pasolini, Norman McAfee, and Craig Owens, "Observations on the Long Take," October 13, Summer (1980): 3-6.

${ }^{26}$ Ibid, 3.

${ }^{27}$ Pasolini, 4.

${ }^{28}$ Ibid, 5.

\section{Bibliography}

Ahmed, Sara. “A Phenomenology of Whiteness.” Feminist Theory 8, no. 2 (2007): 149-68.

AMBmagazine.com. "Women, Selfies, and The Male Gaze - What Really Happens When Girls Take A Selfie," May 4, 2017. http://ambmagazine.com/women-selfies-male-gaze-reallyhappens-girls-take-selfie/. 
Angelino, Lucia. "Motor Intentionality and the Intentionality of Improvisation: A Contribution to a Phenomenology of Musical Improvisation." Continental Philosophy Review 52, no. 2 (June 1, 2019): 203-24. https://doi.org/10.1007/s11007-018-9452-x.

Bollmer, Grant, and Katherine Guinness. "Phenomenology for the Selfie." Cultural Politics 13, no. 2 (July 2017): 156-76.

Conway III, Story by George T. "Unfit for Office." The Atlantic. Accessed April 23, 2021. https://www.theatlantic.com/ideas/archive/2019/10/george-conway-trump-unfitoffice/599128/.

Dean, Aria. "Closing the Loop." The New Inquiry (blog), March 1, 2016. https://thenewinquiry.com/closing-the-loop/.

Foster, Brooke Lea. "The Persistent Myth of the Narcissistic Millennial." The Atlantic, November 19, 2014. https://www.theatlantic.com/health/archive/2014/11/the-persistentmyth-of-the-narcissistic-millennial/382565/.

Freud, Sigmund. "On Narcissism." The Standard Edition of the Complete Psychological Works of Sigmund Freud. Translated by James Strachey, vol. XIV. Hogarth, 1957: 67-102.

Fuchs, Thomas. "The Phenomenology of Body Memory." Body Memory, Metaphor and Movement. Edited by S. C. Koch, T. Fuchs, \& M. Summa, Amsterdam: John Benjamins Publishing, 2012: 9-23.

Fuchs, Thomas, "Temporality and Psychopathology." Phenomenology and the Cognitive Sciences 12 (2013): 75-104.

Gunn, Jenny. "Narcisscinema: Selfie Culture and the Moving Image.” PhD, Georgia State University, 2019.

Gunn, Jenny. "The Gaze in Millennial Culture: Selfies, Instagram and Richard Prince's "New Portraits"." In Material Culture and Third Wave Feminism, 2016. https://www.academia.edu/14738661/The_Gaze_in_Millennial_Culture_Selfies_Instagram _and_Richard_Prince_s_New_Portraits_?source $=$ swp_share.

Gunn, Jenny. "The I in Object: Selfie Culture and Object-Oriented Philosophy." Cinephile 12, no. 1 (Spring 2018): 48-53.

Ibrahim, Yasmin. "Coalescing the Mirror and the Screen: Consuming the 'self' Online." Continuum 31, no. 1 (2017): 104-13.

Ihde, Don. Technology and the Lifeworld: From Garden to Earth. Bloomington: Indiana University Press, 1990.

Lucas, Ryan. "FBI Asks Public For Help Identifying Capitol Riot Suspects Seen Attacking Police.” NPR.org. Accessed April 23, 2021. 
https://www.npr.org/2021/03/18/978644288/fbi-asks-public-for-help-identifying-capitolriot-suspects-seen-attacking-police.

Mitchell, W.J.T. “The Revolution Was Televised.” In the Moment (blog), February 23, 2021. https://critinq.wordpress.com/2021/02/23/the-revolution-was-televised/.

Mogelson, Luke. "Among the Insurrectionists." The New Yorker. Accessed May 28, 2021. https://www.newyorker.com/magazine/2021/01/25/among-the-insurrectionists.

Morse, Nicole. "Selfie Aesthetics: Form, Performance, and Transfeminist Politics in SelfRepresentational Art.” Dissertation, University of Chicago, 2018.

Murray, Derek Conrad. "Notes to Self: The Visual Culture of Selfies in the Age of Social Media - 10253866.2015.1052967." Consumption Markets \& Culture 18, no. 6 (July 7, 2015): $490-516$.

Noonan, Peggy. "Opinion | A Vote to Acquit Trump Is a Vote for a Lie." Wall Street Journal, February 11, 2021, sec. Opinion. https://www.wsj.com/articles/a-vote-to-acquit-is-a-votefor-a-lie-11613084456.

Pasolini, Pier Paolo, Norman McAfee, and Craig Owens. "Observations on the Long Take." October 13 (Summer 1980): 3-6.

Post, Jerrold M., and Stephanie R. Doucette. Dangerous Charisma. Pegasus Books, 2020.

Verbeek, Peter-Paul. "Cyborg Intentionality: Rethinking the Phenomenology of HumanTechnology Relations." Phenomenology and the Cognitive Sciences 7, no. 3 (September 1, 2008): 387-95. https://doi.org/10.1007/s11097-008-9099-x.

Wehrle, Maren. "Being a Body and Having a Body. The Twofold Temporality of Embodied Intentionality." Phenomenology and the Cognitive Sciences 19, no. 3 (July 1, 2020): 499521. https://doi.org/10.1007/s11097-019-09610-z.

Westley, Hannah. "Reading the Self in Selfies." Comparative Critical Studies 13, no. 3 (2016): 371-90.

Williams, Zoe. “Me! Me! Me! Are We Living through a Narcissism Epidemic?” The Guardian, March 2, 2016, sec. Life and style.

http://www.theguardian.com/lifeandstyle/2016/mar/02/narcissism-epidemic-selfobsession-attention-seeking-oversharing.

\section{Author Biography}

Jenny Gunn is a Lecturer in the School of Film, Media \& Theatre at Georgia State University. Her current book project analyzes the impact of the forward-facing camera on contemporary visual culture and historical understandings of the cinema and the self. Jenny is an advisor to the graduate staff of liquid blackness, a research project on blackness and aesthetics. Her writing is published in JCMS, Film-Philosophy, Black Camera, Cinephile, and Mediascape. 